\title{
Natureza humana e cultura: um estudo sobre as concepções psicológicas de John Dewey
}

Pesquisadora: Erika Natacha Fernandes de Andrade

Instituição: Programa de Pós-Graduação (Mestrado) em Psicologia da Universidade de São Paulo (USP)/Faculdade de Filosofia Ciências e Letras de Ribeirão Preto.

Orientador: Prof. Dr. Marcus Vinicius da Cunha

Esta nota de pesquisa tem como objetivo apresentar o projeto Natureza humana e cultura: um estudo sobre as concepções psicológicas de John Dewey, desenvolvido no Programa de Pós-graduação em Psicologia da Faculdade de Filosofia, Ciências e Letras de Ribeirão Preto, da Universidade de São Paulo (USP).

O filósofo norte-americano John Dewey (1859-1952), um dos fundadores do movimento filosófico conhecido como Pragmatismo, escreveu vários títulos sobre educação e filosofia, dedicando-se também a uma série de temas correlatos, como ética, lógica, política, religião e arte (Cunha, 2001, 2002). Em seu principal livro, Democracia e educação, de 1916, o filósofo evidencia a relevância da aferição ou medida dos valores, pois acredita que no âmbito da sociedade é somente compartilhando experiências e refletindo sobre os processos associativos que se chega à consolidação de um meio social democrático (Dewey, 1959).

Segundo Dewey (1958a, 1958b, 1998), os julgamentos de valor não se constituem processos abstratos, espontaneístas, inconscientes, desenvolvidos exclusivamente num campo mental introspectivo. Pelo contrário, as expressões que transmitem valorações constituem-se eventos plenamente passíveis de observação, análise, reflexão, discussão e avaliação, justamente por surgirem de demandas ligadas à realidade concreta e por se referirem a situações que envolvem relações interpessoais e sociais. Nessa perspectiva, Dewey trata de um aspecto fundante: as intenções do juiz, do "self" que valora. Segundo ele, os juízos "não possuem um modus operandi próprio", entrando "em vigor somente pela mediação dos hábitos e tendências daquele que julga" (Dewey, 1958b, p. 228, grifo do autor). Assim o filósofo destaca a necessidade de explicitar e de entender todos os fatores que possam influir e/ou alterar o juízo, uma vez que os indivíduos não são, de forma alguma, neutros ou indiferentes às referências motivacionais. Dewey diz que reconhecer as influências que permeiam o juízo valorativo requer igualmente entender o movimento de constituição da pessoa, todo o mosaico que delicadamente compõe a constituição da natureza humana e sua conduta.

A investigação de maior amplitude do projeto aqui apresentado insere-se, então, no esforço para esclarecer o que John Dewey entende por "natureza humana", no âmbito de suas formulações acerca da construção da consciência e da relação do "eu" com o contexto cultural. Desse eixo central, outros tópicos de estudo são também considerados: a compreensão da estrutura mental do homem moderno; o entendimento da mente humana em seu contexto; os fatores que influenciam a formação da mente; a construção da inteligência em sua relação com as emoções; o papel da comunicação e seu papel na constituição da vida humana e a relação entre natureza humana e conduta. 
O trabalho requer uma pesquisa bibliográfica cuja metodologia está baseada nos parâmetros da teoria da argumentação, na linha investigativa de Perelman (1999) e Perelman e Olbrechts-Tyteca (2002). Por meio desse método, busca-se entender o discurso de John Dewey sobre a temática apresentada e elucidar as bases em que os argumentos do autor se apóiam para viabilizar proposições conclusivas.

Dados preliminares extraídos da obra Human nature and conduct, escrita por John Dewey em 1922, apontam para a desconfiança com que a natureza humana tem sido vista, principalmente quando se mostra relutante em obedecer ao controle que lhe é imposto. O autor considera que a moralidade e os julgamentos valorativos daí decorrentes aparecem com a função de reprimir todo o mal que provém originalmente da natureza do homem. Trata-se de uma moralidade concebida externamente à realidade concreta dos indivíduos e que busca impor regras ao desenvolvimento humano. Dewey (2002, p. 2) critica tais concepções sobre a "essência e origem do controle sobre a natureza humana com o qual a moral tem se ocupado", considerando que em épocas mais antigas, quando o homem ainda não possuía o conhecimento científico da natureza física, aquilo que não podia ser inteligentemente compreendido era passivamente submetido a explicações mágicas. Essa opacidade do entendimento racional da natureza humana resultou na crença que afirma sua irregularidade intrínseca, tendo como conseqüência a divisão dos indivíduos em classes superiores e inferiores e a instauração de regimes oligárquicos, voltados para o controle da natureza irregular do ser humano. $\mathrm{O}$ declínio dessa autoridade social oligárquica, afirma Dewey, fez-se acompanhar por um crescente interesse científico pelo tema da natureza humana, mas determinadas circunstâncias relativas à formação de idéias e ideais morais hegemônicos dificultaram o avanço de uma ciência própria, diferentemente do que se deu no âmbito das ciências físicas. Por isso, a ciência da natureza humana permaneceu rudimentar e embrionária, conclui o autor.

Na continuidade da pesquisa, pretendemos estudar com mais profundidade a obra Human nature and conduct e também outros escritos em que o filósofo aborda o tema da constituição da natureza humana, para evidenciarmos suas proposições, argumentos e interlocuções com outros pensadores. Acreditamos que tal estudo contribuirá para a compreensão de como o autor situa as intenções e os propósitos humanos em sua obra. Contribuirá, igualmente, para um maior esclarecimento de como os saberes da Psicologia compõem um método filosófico capaz de conhecer o universo humano e, assim, permitir o desenvolvimento reflexivo da filosofia.

\section{Referências bibliográficas}

CUNHA, M. V. John Dewey: a utopia democrática. Rio de Janeiro: DPA, 2001.

DEWEY, J. John Dewey: uma filosofia para educadores em sala de aula. 4 ed. Petrópolis: Vozes, 2002.

. Theory of valuation. Chicago: University of Chicago, 1958a.

. Logical conditions of a scientific treatment of morality. In: . Philosophy of education. Iowa: Littlefield, Adams \& Co, 1958b.

. Democracia e educação: introdução à filosofia da educação. Trad. Godofredo

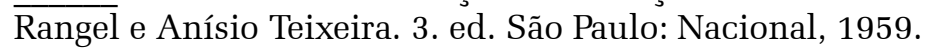

The logic of judgments of practice. In: HICKMAN, L.; ALEXANDER, T. The essential Dewey. Indianapolis: Indiana University Press, 1998. V. 2. Ethics, Logic, Psychology.

. Human nature and conduct: an introduction to Social Psychology. New York: Prometheus Books, 2002. 
Natureza humana e cultura: um estudo sobre as concepções psicológicas de John Dewey

PERELMAM, C. Retóricas. São Paulo: Martins Fontes, 1999.

PERELMAN, C.; OLBRECHTS-TYTECA. Tratado da argumentação: a nova retórica. São Paulo: Martins Fontes, 2002. 